\title{
Zooplankton diversity in Acre state, Amazon, Brazil: an overview of previous studies
}

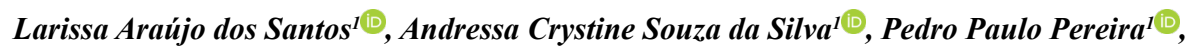 \\ Ronnilda Maria Gonçalves Araujo ${ }^{2}$ \& André Ricardo Ghidini ${ }^{1 *(1)}$ \\ ${ }^{1}$ Universidade Federal do Acre, Centro de Ciências Biológicas e da Natureza, Lablimno, Laboratório de \\ Limnologia, Rodovia BR 364, Km 04, 69920-900, Distrito Industrial, Rio Branco, AC, Brasil. \\ ${ }^{2}$ Universidade de Cuiabá, Laboratório de Microbiologia, Programa de Pós-Graduação em Biocência Animal, \\ Av. Manoel José de Arruda, 3100, 78065-700, Jardim Europa, Cuiabá, MT, Brasil. \\ ${ }^{*}$ Corresponding author: andrericardo83@gmail.com
}

SANTOS, L.A., SILVA, A.C.S, PEREIRA, P.P., ARAUJO, R.M.G., GHIDINI, A.R. Zooplankton diversity in Acre state, Amazon, Brazil: An overview of previous studies. Biota Neotropica 22(1): e20201132. https://doi. org/10.1590/1676-0611-BN-2020-1132

\begin{abstract}
This work assesses current knowledge of zooplankton biodiversity in aquatic ecosystems of the state of Acre (Brazil). A bibliographic survey was undertaken, showing that most of the reported studies have focused on zooplankton diversity and composition. Fifteen locations have been studied. There is still a scarcity of information concerning zooplankton populations in the Amazon region. To date, 170 species of planktonic rotifers have been recorded, distributed in 26 families and 38 genera, together with 18 species of cladocerans, distributed in 8 families and 18 genera, and 4 species of copepods in 2 families and 6 genera. The results indicate the need for further research concerning the biodiversity of this group of organisms at locations in the basins of the Purus and Juruá Rivers, especially in lotic ecosystems and littoral zones, given the present lack of information and the socioeconomic importance they play in the region.

Keywords: Amazon; bibliographic survey; list of species; Rotifera; Cladocera; Copepoda.
\end{abstract}

\section{Diversidade do zooplâncton no estado do Acre, Brasil: uma revisão de estudos anteriores}

\footnotetext{
Resumo: Este trabalho apresenta uma avaliação do estado da arte da biodiversidade do zooplâncton em ecossistemas aquáticos do estado do Acre (Brasil). Um levantamento bibliográfico foi realizado e a maior parte das pesquisas tiveram enfoque na composição e diversidade do zooplâncton. 15 locais foram estudados. AAmazônia ainda é uma região incipiente quanto aos estudos de zooplâncton. Foram registradas 170 espécies de rotíferos planctônicos, distribuídos em 26 famílias e 38 gêneros, 18 espécies de cladóceros distribuídos em 8 famílias e 18 gêneros, e 4 espécies de copépodes distribuídos em 2 famílias e 6 gêneros. Os resultados sugerem ainda a necessidade de mais pesquisas sobre a biodiversidade destes grupos em locais na bacia do Purus e Juruá, bem como em ecossistemas lóticos e nas zonas litorâneas, tendo em vista a carência de informações e a importância socioeconômica que exercem na região.

Palavras-chave: Amazônia; levantamento bibliográfico; lista de espécies; Rotifera; Cladocera; Copepoda.
} 


\section{Introduction}

Biodiversity information is still incomplete for the majority of the aquatic systems in Brazilian Amazonia. There are areas of the Amazon that have never been visited or documented, with many of the species present not having been identified or analyzed in detail (Souza et al. 2019). Although the state of Acre lies in the Amazon basin and is rich in limnic environments, to date there have been only limited studies concerning the aquatic invertebrates present, with emphasis on the phylum Rotifera (Keppeler \& Hardy 2004, Keppeler et al. 2010, Santos Nascimento \& Keppeler 2017), followed by the groups Cladocera and Copepoda (Keppeler 2003a, b, Nascimento \& Keppeler 2017).

The vast majority of taxonomic and ecological studies of the zooplankton community in Acre have been performed in lakes, from the 1990s onwards (Sendacz \& Melo-Costa 1991, Keppeler 2003a, b, Keppeler \& Hardy 2004, Oliveira et al. 2010, Santos et al. 2013). However, only a few studies have investigated the zooplankton of rivers and streams (creeks) (Keppeler et al. 2010, Silva et al. 2014, Nascimento \& Keppeler 2017, Santos Nascimento \& Keppeler 2017).

It is important to emphasize that studies on the composition of zooplankton communities can assist in the environmental management of hydrographic basins, because the presence of groups can vary according to the studied environment. For example, in lentic environments, Cladocera, Rotifera and Copepoda represent about $90 \%$ of the total biomass of zooplankton (Ghidini \& Santos-Silva 2009, Setubal et al. 2020). On the other hand, despite presenting low abundance in relation to other groups in lentic environments, in lotic environments testaceous amoebae can act as protagonists in the environment, especially in streams (Araujo et al. 2019). These groups are the main source of food for species, including fish, acting as a link between producers and consumers at higher levels in the food chain (Iskin et al. 2020). These organisms, which play a fundamental role in nutrient cycling, are sensitive to environmental changes and have rapid responses, which can be used as indicators of the quality and trophic status of aquatic systems (Cardoso et al. 2008, Pinheiro et al. 2019, Karpowicz et al. 2020).

There is limited information available concerning the zooplankton communities in aquatic environments in the state of Acre compared to other regions of Brazil, and there is a growing threat of biodiversity loss in the region due to anthropic activities (Collier et al. 2019). In Brazil, urban development almost invariably results in the unplanned expansion of the urban periphery and the pollution of aquatic ecosystems through the discharge of untreated domestic waste into these environments (IBGE 2011). Agriculture also impacts these environments; sources of pollution derived from those activities are generally related to the disposal of organic materials, such as phosphates and nitrogenated compounds, as well as pesticides and other chemical products (Araújo et al. 2009, García et al. 2016). Therefore, the aim of this work is to summarize current knowledge about the biodiversity of species of the zooplankton community in Acre. This is the first bibliographic survey of zooplankton species found in freshwater environments of this region. Various works concerning biodiversity have highlighted the need for biological databases, as part of efforts to improve programs for the conservation of biota and ecosystems (Groombridge 1992, Heywood 1995). Undertaking a bibliographic survey can contribute to collective knowledge and indicate areas where further work is needed. It can assist with understanding the issues or, when appropriate, reusing and replicating research at different scales and in different contexts (Galvão 2010).

\section{Material and Methods}

This study contemplated published papers regarding studies performed in two of the most important water basins of the State of Acre (Purus and Juruá rivers). The Purus River basin, located in southwestern Amazonia, is the fourth largest $\left(370,000 \mathrm{~km}^{2}\right)$ among the seven tributary river basins on the right bank of the Amazon River. Its area within Brazil covers around $354,000 \mathrm{~km}^{2}$, distributed in 32 municipalities in the states of Acre, Amazonas, and Rondônia (ANA 2011).

The hydrographic basin of the Juruá River is shared between Brazil (states of Acre and Amazonas) and Peru (Ucayali Department). Within Acre, there are eight municipalities in the basins of the Juruá River and its main tributaries, the Tarauacá and Envira Rivers, covering an area of $74,950 \mathrm{~km}^{2}$. This area corresponds to approximately $49 \%$ of the state of Acre, $19.9 \%$ of the area of the Solimões/Juruá/Japurá basin (considering its entire course within the Amazon region), and 1.9\% of the Brazilian part of the Amazon basin (ACRE 2012).

The zooplankton inventory for limnic aquatic ecosystems in Acre was produced based on a review of the information available in scientific journals up to 2017, given that there are no other publications for the state of Acre on zooplankton after this year. For this search, we used the keywords "zooplankton," "rotifera," "cladocera," "copepoda," "testacea," and "acre", in Google Scholar (http://scholar.google.com). All results were then filtered considering the following criteria: i) it was published in a scientific journal (indexed or not); ii) it was performed in natural environments (lakes, streams, rivers); and iii) it contained a composition table. Unpublished works (dissertations and theses) and conference abstracts were not considered.

Table 1 provides information about each study (where available), including the geographic coordinates, basin, and hydrological system. It is known that the basins of the Purus and Juruá Rivers are found in other regions; therefore, only water bodies located within the territorial limit of the state of Acre were considered, that is, areas outside that limit were discarded.

We compiled the taxa composition data based on the articles' tables, without performing any calculations, corrections, and processing, considering the purpose of this article was to group the information already published regarding the zooplankton community.

In the present review, the names of the species are as recorded by the authors, but, when necessary, the currently valid names according to taxonomic reviews are also included. After the review, the species are listed according to the classification separated by family, genus, and species proposed by Segers (2007). Some species have been cited more than once for the same environment but have been considered only once for each environment. It should be noted that in these procedures, citations only of morphotypes (for example, Rotatoria sp. or Rotifera sp. 1) were excluded if not in the generic level.

\section{Results}

A total of 11 studies were found, distributed between two basins. In the Purus basin, studies were found in the Acre river and the lakes Amapá and Pirapora. Regarding the Juruá basin, the Sacado, Pedernal, Anil, Preto and Jesumira streams and the Canela Fina, Cigana, Novo, Verde, Monju, St. Elias and Miritizal lakes were studied (Table 1 and Figure 1). The main sampling method was vertical and horizontal pulls using zooplankton nets. In most of these studies, 50-55 $\mu \mathrm{m}$ plankton 
Table 1. List of water bodies in which zooplankton studies were performed, with their respective geographic coordinates and studies list.

\begin{tabular}{|c|c|c|c|}
\hline Basin & System & Coordinates & Studies \\
\hline \multirow{7}{*}{ Purus } & \multirow{4}{*}{ Amapá Lake } & \multirow{4}{*}{$\begin{array}{l}10^{\circ} 02^{\prime} 36^{\prime \prime S} \text { e } \\
67^{\circ} 50^{\prime} 24 ’ \mathrm{~W}\end{array}$} & Keppeler E., 2003b \\
\hline & & & Keppeler E., 2003a \\
\hline & & & $\begin{array}{c}\text { Sendacz \& Melo-Costa, } \\
1991\end{array}$ \\
\hline & & & $\begin{array}{c}\text { Keppeler \& Hardy, } \\
2004\end{array}$ \\
\hline & Pirapora & $9^{\circ} 27^{\prime} 21^{\prime \prime S}$ e & Keppeler E., 2003b \\
\hline & Lake & $67^{\circ} 31^{\prime} 30^{\prime \prime} \mathrm{W}$ & Keppeler E., 2003a \\
\hline & Acre River & $\begin{array}{c}7 \text { e } 12^{\circ} \mathrm{S} \text { e } 66 \text { e } \\
74^{\circ} \mathrm{W}\end{array}$ & $\begin{array}{c}\text { Sendacz \& Melo-Costa, } \\
1991\end{array}$ \\
\hline \multirow{13}{*}{ Juruá } & $\begin{array}{l}\text { Sacado } \\
\text { Stream }\end{array}$ & $\begin{array}{l}\text { 7०33'0”'S e } \\
73^{\circ} 36^{\prime} 0 \text { ' W }\end{array}$ & Nascimento \& \\
\hline & Dedornet & ה & \\
\hline & $\begin{array}{l}\text { Pedernal } \\
\text { Stream }\end{array}$ & $\begin{array}{l}7^{\circ} 30 ' 23,7^{\prime}{ }^{\prime} \mathrm{Se} \\
73^{\circ} 42^{\prime} 05,2^{\prime \prime} \mathrm{W}\end{array}$ & Silva et al., 2014 \\
\hline & Anil Stream & $\begin{array}{l}7^{\circ} 27^{\prime} 0124^{\prime \prime} \mathrm{S} \mathrm{e} \\
73^{\circ} 37^{\prime} 30,8^{\prime \prime} \mathrm{W}\end{array}$ & Silva et al., 2014 \\
\hline & Preto Stream & $\begin{array}{l}7^{\circ} 35 " 38,46 ” \mathrm{~S} \text { e } \\
72^{\circ} 4316,46 ” \mathrm{~W}\end{array}$ & Oliveira et al., 2010 \\
\hline & $\begin{array}{l}\text { Jesumira } \\
\text { Stream }\end{array}$ & $\begin{array}{l}7^{\circ} 28^{\prime} 10,2^{\prime \prime} \mathrm{S} \\
73^{\circ} 33^{\prime} 54,6 ”\end{array}$ & Keppeler et al., 2010 \\
\hline & $\begin{array}{c}\text { Canela Fina } \\
\text { Lake }\end{array}$ & $\begin{array}{l}7^{\circ} 33^{\prime} 40,63 ” \mathrm{Se} \\
72^{\circ} 42^{\prime} 55,95^{\prime \prime} \mathrm{W}\end{array}$ & Oliveira et al., 2010 \\
\hline & Cigana Lake & $\begin{array}{c}\text { 7³4'15”S; } \\
\text { 72³7'57’'W }\end{array}$ & Santos et al., 2013 \\
\hline & Novo Lake & $\begin{array}{l}\text { 744'01'’s; } \\
72^{\circ} 37^{\prime} 566^{\prime \prime} \mathrm{W}\end{array}$ & Santos et al., 2013 \\
\hline & Verde Lake & $\begin{array}{l}\text { 7०50’02”'s; } \\
\text { 72³8'21'”W }\end{array}$ & Santos et al., 2013 \\
\hline & Monju Lake & $\begin{array}{l}\text { 748'51'’s; } \\
72^{\circ} 36^{\prime} 37^{\prime \prime} \mathrm{W}\end{array}$ & Santos et al., 2013 \\
\hline & $\begin{array}{c}\text { Santo . Elias } \\
\text { Lake }\end{array}$ & $\begin{array}{c}7^{\circ} 46^{\prime} 19^{\prime \prime} \mathrm{S} \\
72^{\circ} 36^{\prime} 37^{\prime \prime} \mathrm{W}\end{array}$ & Santos et al., 2013 \\
\hline & $\begin{array}{l}\text { Miritizal } \\
\text { Lake }\end{array}$ & Not available & $\begin{array}{l}\text { Nascimento \& } \\
\text { Keppeler, } 2017\end{array}$ \\
\hline
\end{tabular}

nets were used, the $50-\mu \mathrm{m}$ size net being used in the studies by Sendacz \& Melo-Costa (1991), Keppeler et al. (2010) and Silva et al. (2014). In the studies by Keppeler (2003a, b), Keppeler \& Hardy (2004), Santos et al. (2013), Nascimento \& Keppeler (2017), and Santos Nascimento \& Keppeler (2017), $55 \mu \mathrm{m}$ nets were used. It was not possible to determine, based on what the authors described, the total number of samples or the water volume that was filtered/taken in all the studies.

Up to now, studies in Acre have described 170 species of Rotifera (Table 2 and Figure 2), 18 species of Cladocera, 2 of Copepoda Cyclopoida, and 2 of Copepoda Calanoida (Table 3 and Figure 3). Planktonic fauna populations have been studied in 15 freshwater environments, 3 of them at more than one time, mainly in the southwestern Amazon region (Figure 1).

When considering all zooplankton groups, a total of 164 species were recorded in the Juruá River basin, while 73 species were found in the
Purus River basin. The most studied periods were summer and winter; in the Amazon, these are known periods of drought and flood, respectively.

Research concerning plankton from limnic environments in Acre began in the southwestern region of the state, with Sendacz \& Melo-Costa (1991) recording 32 species and 14 organisms at the genus level for Rotifera, 6 species and 1 organism at the genus level for Cladocera, and 2 species and 3 organisms at the genus level for Copepoda Cyclopoida. Moreover, larval and juvenile forms of copepods (nauplii and copepodites) were also recorded for the two water bodies. The first major species surveys in lakes and streams were undertaken from 2000 onwards, as reported by Keppeler (2003a, b), Keppeler \& Hardy (2004a), Keppeler et al. (2010), Oliveira et al. (2010), Santos et al. (2013), Silva et al. (2014), Nascimento \& Keppeler (2017), and Santos Nascimento \& Keppeler (2017).

In this data compilation, 26 families of rotifers were recorded, among which the most representative families were Lecanidae (41 species), Brachionidae (38), Lepadellidae (17), and Filinidae (9). The overall richness in Acre was 170 rotifers identified at the species level and 34 identified only at the genus level, totaling 204 taxa. A total of 149 species of Rotifera were recorded for the Juruá River basin, while 58 were recorded for the Purus River basin, with 37 species being common to the two basins. Among the species studied, 21 were reported only in the Purus River basin and 112 only in the Juruá River basin.

In the Cladocera group, the species identified were distributed in 8 families, with the Chydoridae family presenting the greatest richness (5 species), followed by the families Sididae (3), Daphnidae (3), Bosminidae (2), Moinidae (2), and Ilyocryptidae (2). The dominant species, occurring in more than $70 \%$ of the environments and therefore classified as very frequent, were Bosminopsis deitersi, Moina minuta, and Moina reticulata. In the Juruá River basin, 15 species were registered, and in the Purus basin, 9 were registered; 6 species were common between the two basins. Among the species studied, 3 were described only in the Purus River basin and 9 occurred only in the Juruá River basin.

The Copepoda group showed a difference in terms of its distribution, because it was only found in white water environments (with records only for the Purus River basin). Eight taxa were recorded, of which 4 were identified at the species level and 4 at the genus level, distributed in the families Diaptomidae and Cyclopidae, with a total of 6 genera. The family with the greatest representation was Cyclopidae, with 5 taxa recorded, while 3 species were recorded for Diaptomidae. The larval and juvenile phases (such as copepodites and nauplii) were found in the two basins studied. For the Juruá basin, only the juvenile forms of the copepods (nauplii and copepodites) were registered.

For the environments and basins studied, the Juruá River basin presented greater richness and species diversity compared with the Purus River basin. In the case of the water bodies, Amapá Lake showed the greatest Rotifera richness, followed by Anil Stream and Verde Lake. Preto and Jesumira streams presented the lowest richness and diversity. The findings indicate that Rotifera diversity is higher in lentic environments and lower in lotic environments.

\section{Discussion}

Given that the basins of the Juruá and Purus Rivers cover vast areas and are of great importance for the Amazon basin, it can be considered 
Santos, LA. et al.

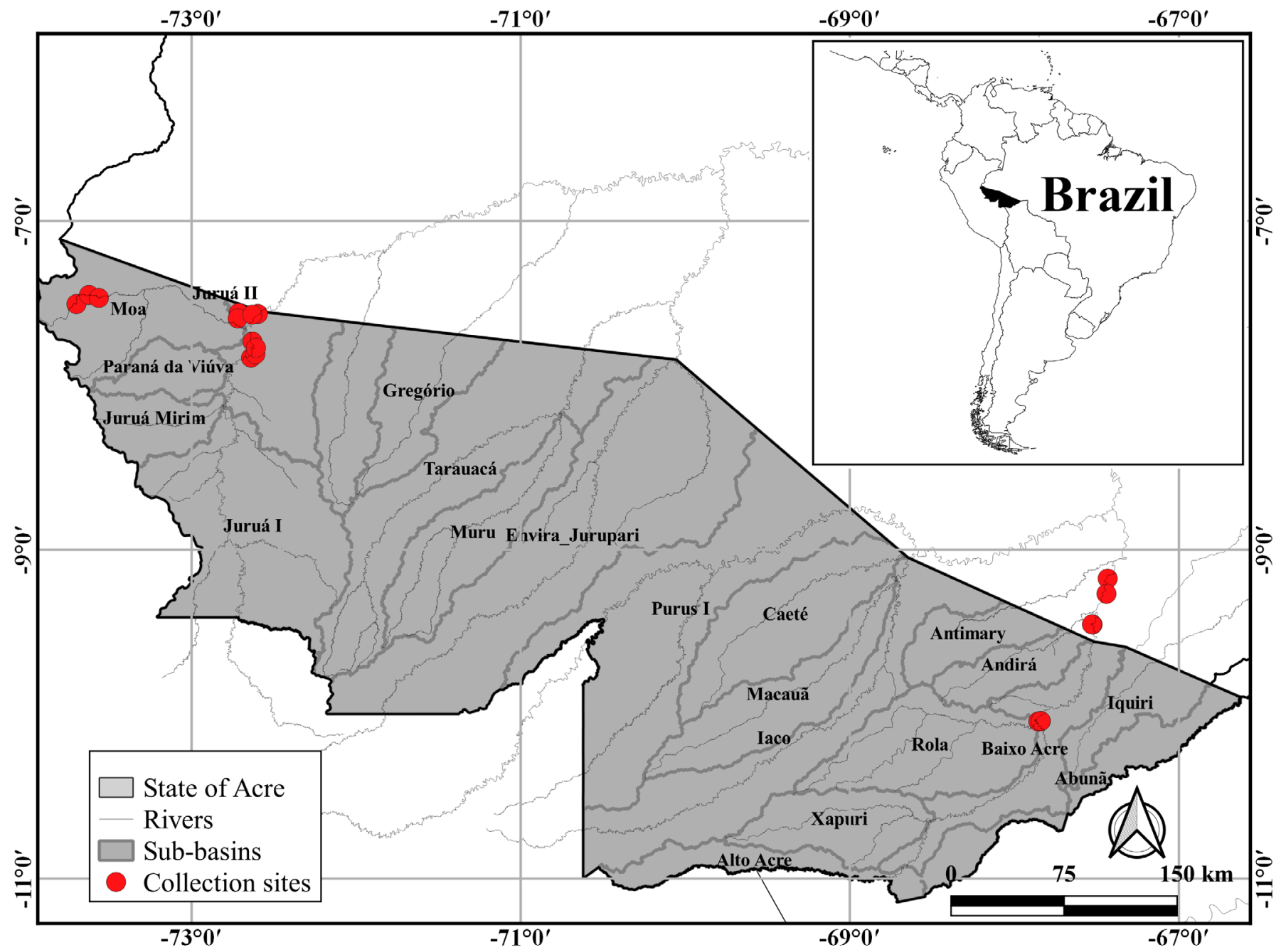

Figure 1. Map with study sites in which previous published papers have been performed.

that studies of the aquatic invertebrate community are still scarce. There has been greater emphasis on studies concerning lakes and the Rotifera phylum in Acre, as seen in the studies of Keppeler \& Hardy (2004), Keppeler et al. (2010), Do Nascimento \& Keppeler (2017), and Santos Nascimento \& Keppeler (2017). Compared with other communities of organisms, the numbers are quite low and are mostly related to a specific group rich in Rotifera. This scarcity of information may be due to a lack of specialists dedicated to the different zooplankton taxonomic groups, as well as the difficulties in access and the limited resources and infrastructure available to researchers. Nonetheless, the environments studied showed high species diversity, mainly due to the great heterogeneity of habitats. This richness and diversity of zooplankton in Acre can be compared with data for the floodplain lakes in the Itacoatiara region of Amazonas (Ghidini et al. 2018). Given the high richness of 43 species in the 4 studied lakes, the most abundant rotifers with 21 species, cladocerans and copepods with quantities and species similar to those found in the state of Acre. Nauplii and copepodites were also found.

Based on the collected studies, Rotifera was the most diverse group, with the greatest number of species recorded, following the same pattern for all the water bodies. This pattern is common in tropical environments
(Rocha et al. 1995) and can be attributed to three factors, namely the high population growth rates of this group (Allan 1976) the fact most species of this group inhabits freshwater environments and the emphasis given to the group in these particular published studies (Keppeler \& Hardy 2004, Keppeler et al. 2010). Due to the hydrological conditions of the aquatic ecosystems in the Amazon, communities tend to present recurrent variations in each type of environments in which they are present, which explains the greater wealth and diversity in the lakes and less wealth and diversity in the lotic environments studied (Esteves 1998, Lair 2006), as lakes constitutes a more stable environment for Rotifers to develop. In addition, regional climate patterns affect riverside and lake floodplains in similar ways, despite general differences in their linkages with basins (Wantzen et al. 2008). The sampling effort can be one of the reasons for such diversity of Rotifera, being registered in the studies of Sendacz \& Melo-Costa (1991), Keppeler (2003a), Keppeler (2003b), Keppeler \& Hardy (2004), Oliveira et al. (2010), Keppeler et al. (2010), Santos et al. (2013), Silva et al. (2014), Nascimento and Keppeler (2017) and Santos Nascimento \& Keppeler (2017).

In the first study, performed by Sendacz \& Melo-Costa (1991), rotifers showed the highest species diversity among the groups studied, with a total of 46 species, including 11 belonging to the genus 
Table 2. Rotifera species list in limnic ecosystems of Acre State, indicating species location, considering studies published so far.

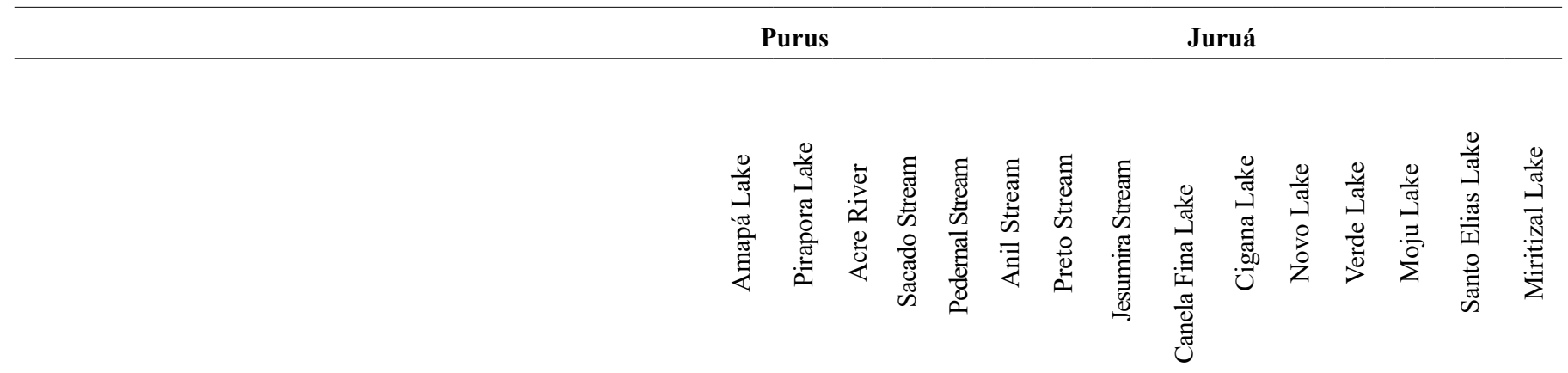

\section{Rotifera}

Adineta barbata (Janson, 1893)

Epiphanes spp.

Keratella híspida (Lauterborni, 1900)

Keratella lenzi (Hauer, 1953)

Keratella lenzi heliaca (Berzins, 1955)

Keratella lenzi lenzi (Hauer ,1953)

Keratella sp.

Lecane acus (Harring, 1913)

Lecane decipiens (Murray, 1913)

Ascomorpha spp.

Adineta gracilis (Janson, 1893)

Adineta sp.

Anuraeopsis coelata (De Beauchamp, 1932)

Anuraeopsis fissa (Gosse, 1851)

Anuraeopsis navicula (Rousselet, 1911)

Anuraeopsis sp.

Ascomorpha ecaudis (Perty, 1850)

Ascomorpha ovalis (Bergendal, 1892)

Ascomorpha saltans (Bartsch, 1870)

Ascomorpha sp.

Asplanchna brightwellii (Gosse, 1850)
$\mathrm{X}$

X

X X

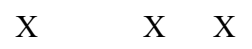

X

X

$\mathrm{X}$

$\mathrm{X}$

$\mathrm{X}$

X

$\mathrm{X}$

X

X X X

X X

$\mathrm{X}$

X

X X

X $\quad X$

X X

X

X X

X X

X $\quad X$

X

X $\quad X \quad X$

X X

X 
Asplanchna cf. (Herrickii De Gueme, 1850)

Asplanchna sieboldi (Leydig, 1854)

Asplanchna sp.

Beauchampiella eudactylota eudactylota (Gosse, 1886)

Brachionus angularis (Gosse, 1851)

Brachionus bidentatus (Anderson, 1889)

Brachionus bidentatusbidentatus (Anderson, 1889)

Brachionus bidentatusf.inermis(Rousselet, 1906)

Brachionus budapestenensis (Daday, 1885)

Brachionus calyciflorus (Pallas, 1766)

Brachionus calicyflorus anuraeformis (Brehm, 1903)

Brachionus caudatus (Barrois \& Daday, 1884)

Brachionus diversicornis (Daday, 1883)

Brachionus dolabratus (Harring, 1914)

Brachionus falcatus (Zacharias, 1898)

Brachionus havanaensis (Rousselet, 1911)

Brachionus mirus (Daday, 1905)

Brachionus mirus f.laticaudatus (Paggi, 1973)

Brachionus mirusvar.reductus(Koste, 1972)

Brachionus patulus var. macrocanthus (Jakubski, 1912)

Brachionus plicatilis (Müller, 1786)

Brachionus quadridentatus mirabilis(Daday, 1897)

Brachionus quadridentatus(Hermann, 1783)

Brachionus sp.

Brachionus tridentata (Anderson, 1889)

Brachionus urceolaris (Müller, 1773)

Brachionus zahniseri (Ahlstrom, 1934)

Cephalodella gibba (Ehrenberg, 1830)
Santos, LA. et al.
$\mathrm{X}$

$\begin{array}{lllllll}X & X & & & X & X \\ X & & X & X & X & X\end{array}$

$\mathrm{X}$

X X

X X

$\mathrm{X}$

$\mathrm{X}$

X

X

$\begin{array}{lllll}\text { X } & \text { X } & & \\ \text { X } & \text { X } & & \\ & & & \\ \text { X } & \text { X } & \text { X } & \text { X }\end{array}$

$\begin{array}{llllll}X & X & X & X & X & X\end{array}$

$\mathrm{X}$

$\begin{array}{lll}X & X & X \\ X & X & \\ X & X & \end{array}$

$\begin{array}{lllll}X & X & X & X & X\end{array}$

$\begin{array}{llllll}X & X & X & X & X & X\end{array}$

$\begin{array}{llll}X & X & X & X\end{array}$
X X

X $\quad \mathrm{X}$

X

X

X $\quad \mathrm{X}$
X X
$\mathrm{X}$

X 
Euchlanis sp.

Euchlanis spp. 
Filinia saltator (Gosse, 1886)

Filinia sp.

Filinia terminalis (Plate, 1886)

Floscularia sp.

Gastropus stylifer (Imohof, 1891)

Hexarthra intermedia braziliensis (Hauer, 1953)

Hexarthra intermedia (Wiszniewski, 1929)

Hexarthra mira (Hudson, 1871)

Hexarthra sp.

Keratella americana (Carlin, 1943)

Keratella cochlearis cochlearis (Plate, 1886)

Keratella cochlearis (Gosse, 1851)

Keratella cochlearis hispida (Lauterborn, 1900)

Keratella tropica tropica(Apstein, 1907)

Keratella tropica(Apstein, 1907)

Lecane aculeata (Jakubski, 1912)

Lecane acus (Harring, 1913)

Lecane arcuata $\mathrm{cf}$. (Bryce, 1891)

Lecane benjamini brasiliensis (Koste, 1972)

Lecane bulla (Gosse, 1851)

Lecane bulla goniata (Harring \& Meyers, 1896)

Lecane cf. furcata (Murray, 1913)

Lecane cf. murrayi (Hauer, 1965)

Lecane cf. stichaea verecunda (Harring \& Myers, 1926)

Lecane clara (Bryce, 1892)

Lecane closterocerca amazonica (Koste, 1972)

Lecane closterocerca(Schmarda, 1859)
$\mathrm{X}$

X

X

X

$\mathrm{X}$

X X X

$\mathrm{X}$

X

X X X

X $\quad$ X

X X

$\begin{array}{llllll}X & X & X & X & X & X\end{array}$

X X X

X $\quad \mathrm{X} \quad \mathrm{X}$

$\mathrm{X}$

$\begin{array}{lllll}X & X & X & X & X\end{array}$

X X X

$\mathrm{X}$

X X

X

$\mathrm{X}$

X

X

X

X

X

X $\quad$ X $\quad$ X

X

X

X

$\mathrm{X}$

$\mathrm{X}$

X

X

$\begin{array}{ll}X & X\end{array}$

X

X

$\mathrm{X}$ 
Lecane curvicornis(Murray, 1913)

Lecane decipiens (Murray, 1913)

Lecane doryssa $\mathrm{cf}$. (Harring, 1914)

Lecane elegans (Harring, 1914)

Lecane elsa (Hauer, 1931)

Lecane flexilis (Hudson \& Gosse, 1886)

Lecane grandis (Murray, 1913)

Lecane imbricata (Carlin, 1939)

Lecane inermis (Bryce, 1892)

Lecane kutikova (Koste, 1978)

Lecane lauterborni (Hauer, 1924)

Lecane leontina (Turner, 1892)

Lecane ludwigii (Eckstein, 1883)

Lecane luna (Müller, 1776)

Lecane lunaris constricta (Murray, 1930)

Lecane lunaris crenata (Harring, 1930)

Lecane lunaris (Ehrenberg, 1838)

Lecane lunaris lunaris (Ehrenberg, 1832)

Lecane lunaris perplexa (Alstrom, 1938)

Lecane murrayi (Koste, 1978)

Lecane monostyla (Daday, 1897)

Lecane papuana (Murray, 1913)

Lecane pauliane $\mathrm{cf}$. (Berzins, 1960)

Lecane pyriformis (Daday, 1905)

Lecane quadridentata (Ehrenberg, 1832)

Lecane sola (Hauer, 1926)

Lecane sp.
X $\quad$ X $\quad$ X

$\mathrm{X}$

X X X

X

X

X X

X X X

X

X

$\mathrm{X}$

$\mathrm{X}$

X

X

X X

X

X

X

X

X

X

X X

$\mathrm{X}$

X

X

$\begin{array}{lllll}X & X & X & X & X\end{array}$

X

X X X

$\mathrm{X}$

$\begin{array}{lllll}X & X & X & X & X\end{array}$

$\mathrm{X}$

X X

X

X

X

X X X

$\begin{array}{llllll}X & X & X & X & X & X\end{array}$

X $\quad \mathrm{X} \quad \mathrm{X}$

X $\quad$ X $\quad X \quad X$

$\mathrm{X}$
X

$\mathrm{X}$

X

X 
Lecane spp.

Lecane stichaea $\mathrm{cf}$. verecunda (Harring \& Myers, 1926)

Lecane stichaea (Harring, 1913)

Lepadella akrobeles (Myers, 1934)

Lepadella acuminata (Ehrenberg, 1834)

Lepadella astacicola (Hauer, 1926)

Lepadella benjamini benjamini (Harring, 1916)

Lepadella $\mathrm{cf}$. benjamini (Harring, 1916)

Lepadella cf. princisi (Berzins, 1943)

Lepadella costatoides (Segers, 1992)

Lepadella favorita (Klemet, 1962)

Lepadella imbricata (Harring, 1914)

Lepadella minuta (Weber \& Montet, 1918)

Lepadella oblonga (Ehrenberg, 1834)

Lepadella ovalis (Müler, 1786)

Lepadella patella (Müller, 1786)

Lepadella patella similis (Remane, 1929)

Lepadella princisi (Berzins, 1943)

Lepadella rhomboides (Gosse, 1886)

Lepadella sp.

Lepadella triptera triptera (Ehrenberg, 1930)

Paracolurella logima (Myers, 1924)

Lindia fulva (Harring \& Myers, 1922)

Macrochaetus collinsi (Gosse, 1867)

Macrochaetus sericus (Thorpe, 1893)

Macrochaetus sp.
X X

$\mathrm{X}$

X

X

X

X

$\mathrm{X}$

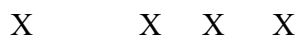

X X

X

$\mathrm{X}$

$\mathrm{X}$

$\mathrm{X}$

X

$\begin{array}{llllllll}X & X & X & X & & X & X \\ X & X & X & X & X & X & & \end{array}$

X X

X

X X

$\mathrm{X}$

X X
$\begin{array}{lllll}X & X & X & X & X\end{array}$

X
$\mathrm{X}$

X X

$\mathrm{X}$

X

$\mathrm{X}$
X

X
X 
Monommata sp.

Mytilina bisulcata (Lucks, 1912)

Mytilina sp.

Mytilina ventralis macracantha(Gosse, 1886)

Notommata sp.

Paranuraeopsis sp.

Platyias leloupi (Gillard, 1957)

Platyias quadricornis brevispinus (Daday, 1905)

Platyias quadricornis (Ehrenberg, 1832)

Platyias quadricornis quadricornis (Ehrenberg, 1832)

Platyionus patulus fa. Macrodactyla (Hauer, 1965)

Platyionus patulus macrachanthus (Daday, 1905)

Platyionus patulus (Muller, 1786)

Platyionus patulus patulus (Muller, 1786)

Polyarthra bicerca (Wulfert, 1956)

Polyarthra dolichoptera (Idelson, 1925)

Polyarthra remata (Skorikov, 1896)

Polyarthra sp.

Polyarthra vulgaris (Carlin, 1943)

Proales doliaris (Rousselet, 1895)

Proales sp.

Sinantherina sp.

Synchaeta sp.

Testudinella cf. aspis (Carlin, 1939)
$\mathrm{X}$

$\mathrm{X}$

X

$\mathrm{X}$

$$
\begin{array}{lllll}
X & X & X & X & X
\end{array}
$$

$\mathrm{X}$

X

$\mathrm{X}$

X $\quad X \quad X$

$\mathrm{X}$

X

X

X X

X

X $\quad \mathrm{X}$

X

$\mathrm{X}$

X

X X

$\begin{array}{llll}X & X & X & X\end{array}$

$\mathrm{X}$

X

X $\quad$ X $X$

X $\quad \mathrm{X}$

$\begin{array}{llllll}X & X & X & X & X & X\end{array}$

$\mathrm{X}$

$\begin{array}{lllll}X & X & X & X & X\end{array}$

$\mathrm{X}$

X

Testudinella mucronata (Gosse, 1887) 
Testudinella mucronata hauerensis (Gillard, 1967)

Testudinella parva (Ternetz, 1892)

Testudinella patina (Hermann, 1783)

Testudinella patina f. trilobata (Shephard, 1892)

Testudinella patina intermedia Anderson, 1889

Testudinella sp.

Testudinella tridentata (Smirnov, 1931)

Trichocerca bicristata Gosse, 1887

Trichocerca bidens (Lucks, 1912)

Trichocerca capucina (Wierzejski \& Zacharias, 1893)

Trichocerca chattoni(Beauchamp, 1907)

Trichocerca montana $\mathrm{cf}$. (Hauer, 1956)

Trichocerca myersi (Hauer, 1931)

Trichocerca similis (Wierzejski, 1893)

Trichocerca sp.

Trichocerca spp.

Trichocerca tenuior (Gosse, 1886)

Trichotria tetractis (Ehrenberg, 1830)

Trochosphaera aequatorialis (Semper, 1872)
$\mathrm{X}$

$\mathrm{X}$

X

$\mathrm{X}$

$\mathrm{X}$

X X

X $\quad X \quad X$

X X

$\begin{array}{llll}X & X & X & X\end{array}$

X

X

X

X

X X

X

X X

$\mathrm{X}$

$\begin{array}{lllll}X & X & X & X & X\end{array}$

X

X X

X $\quad X \quad X$

X
X

X

X

X

X

Wierzejskiella sabulosa (Wiszniewski, 1932)

X

Brachionus, which has a high degree of endemism in South America and Australia (Ruttner-Kolisko 1972, Pejler et al. 1977 apud Brandorff et al. 1982, Dumont 1983, Rocha et al. 1995, Sendacz et al. 2006, Santos et al. 2014). The species that occurred in only one of the environments studied were Brachionus mirus voigti, Brachionus zahniseri gessneri, and Trichocerca chattoni (Lua Nova Lake); Brachionus mirabilis, Brachionus bidentatus inermis, and Mytilina sp. (Amapá Lake); and Brachionus bidentatus, Brachionus mirus laticaudatus, and Brachionus quadridentatus (Acre River). Robertson \& Hardy (1984) analyzed the zooplanktonic composition in Central Amazonia, comparing several várzea lakes, and found that the rotifers were not restricted to any particular type of water in the region.
Studies were only continued in 2003, when Keppeler (2003a) investigated two ecosystems (Pirapora and Amapá Lakes) to identify differences in the abundances of invertebrates in the pelagic and littoral zones and the diurnal variation. The pelagic and littoral zones of those two studied lakes did not show any statistically significant difference and the vertical distribution of Rotifera was found to be uniform in the lakes, in contrast to the other groups analyzed. The author related these results with the sampling period, as cycles of inundation could exert a homogenizing effect, but also indicates the need for further studies.

Later in the same year, Keppeler (2003b) compared the zooplanktonic compositions in Pirapora and Amapá Lakes. Rotifera was the most abundant group, with 38 species and the greatest abundance of the family Brachionidae, followed by Filinidae. The Rotifera group 
Zooplankton diversity in Acre state

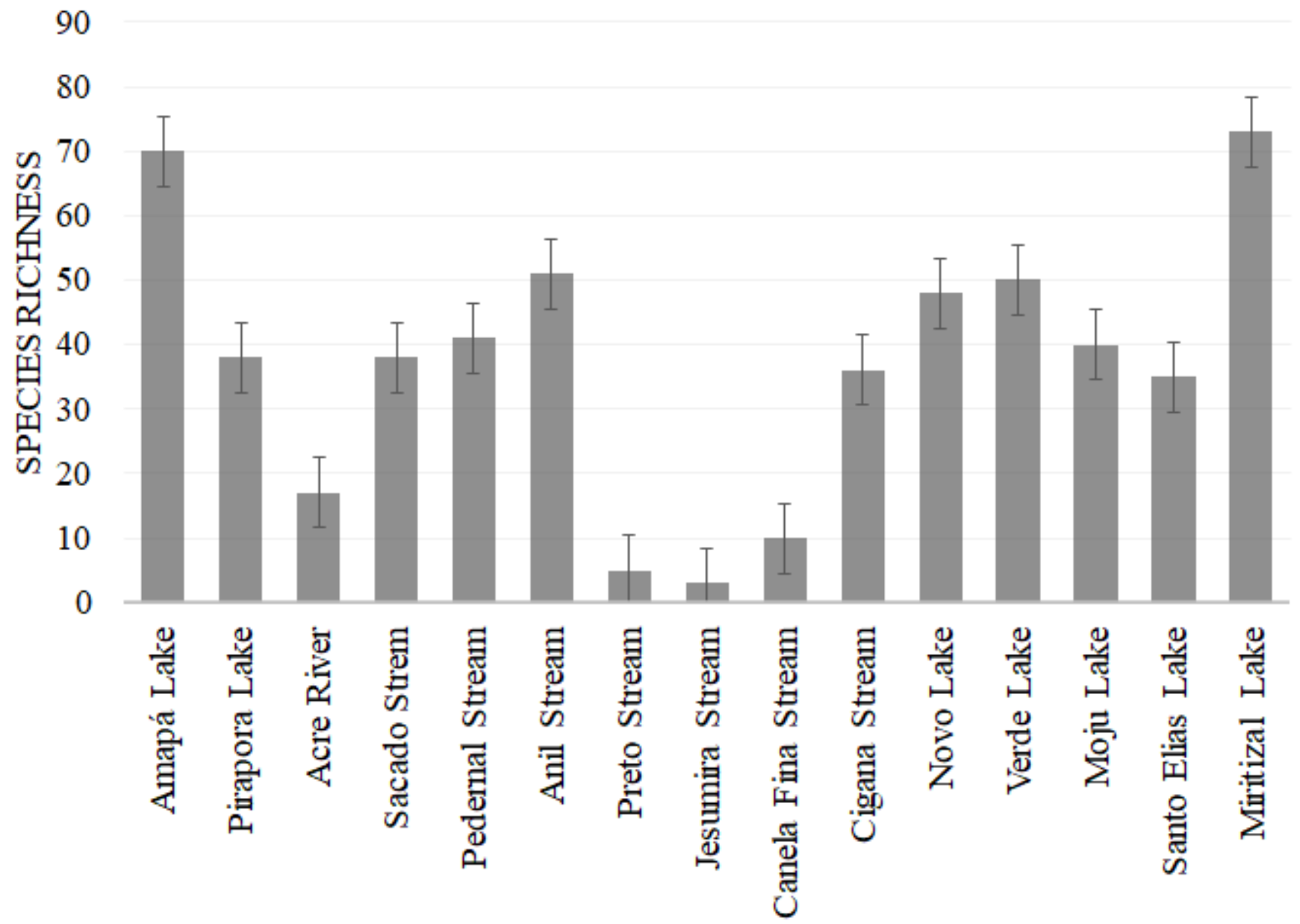

Figure 2. Rotifera species richness in each environment in previously published papers of Acre State. Brazil.

had more species identified in different aquatic environments in this part of the Amazon basin. In the same basin, this group of organisms showed the highest species diversity in the studies by Hardy (1980), Koste \& Robertson (1983), Hardy et al. (1984), Robertson \& Hardy (1984), Sendacz \& Melo-Costa (1991), and Bozelli (1992). Similar findings were reported for other environments (Sharma \& Sharma 2001, Lansac-Tôha et al. 2009). Birky and Gilbert (1971) suggested that the reproductive systems of rotifers have several advantages that favor the activity of most of these animals as opportunists, due to their rapid reproduction and adaptation.

In later work, Keppeler \& Hardy (2004) undertook a survey of the abundance and composition of rotifers in Amapá Lake during low water and flood periods. The Rotifera composition included 48 species, 20 of which were newly recorded for the Acre River floodplain, while some species were common. The following genera occurred in the dry period: Asplanchna, Brachionus, Epiphanes, Filinia, Keratella, and Polyarthra. During the flood period, the following genera predominated: Brachionus, Filinia, Keratella, Trichocerca, and Polyarthra.

The rotifers showed greater occurrence during the dry period, especially the following species: Asplanchna brightwelli (Gosse, 1850), Asplanchna sieboldi (Leydig, 1854), Brachionus calicyflorus anuraeformis, Filinia longiseta (Ehrenberg, 1834), Filinia terminalis (Ehrenberg, 1834), Filinia opoliensis (Zacharias, 1898), Keratella cochlearis (Plate, 1886), and Keratella cochlearis hispida (Lauterborn 1900). The use of Pearson's correlation coefficients showed significant correlations $(p<0.05)$ between environmental variables and the density of rotifers. Specifically, electrical conductivity was negatively correlated with the density of rotifers in the low-water phase $(r=-0.8824, p<0.05)$, and was negatively correlated with depth in the high-water phase $(\mathrm{r}=$ $-0.7513, \mathrm{p}<0.05$ ). Seasonal changes, caused by water level fluctuations, and low niche diversification influenced the composition and abundance of the studied group (Keppeler \& Hardy 2004).

Based on the reviewed studies, the most frequently observed family was Brachionidae, followed by the family Lecanidae, which is predominant in tropical environments. Carvalho (1983) also reported the dominant occurrence of these families, found in abundance in Amazon aquatic environments. The number of species of the zooplankton community in Amapá Lake could be attributed to the variety of niches available during the phases of the hydrological cycle (drought and flood) and to the absence of aquatic plants. The number was low compared with the diversity reported for other basins and várzea lakes.

Oliveira et al. (2010) found a predominant occurrence of rotifers in Preto stream, representing the greatest diversity of organisms, with 18 individuals. Newly recorded species of rotifers in Acre included Lecane lunaris, Lecane quadridentata, Lecane kutikova, Dissotrocha aculeata, and the genera Dissotrocha and Macrochaetus. Aoyagui \& Bonecker (2004) reported 
Table 3. Cladocera and Copepoda species list and Copepodites and Nauplii in limnic ecosystems of Acre State, indicating species location, considering studies published so far.

Purus Juruá

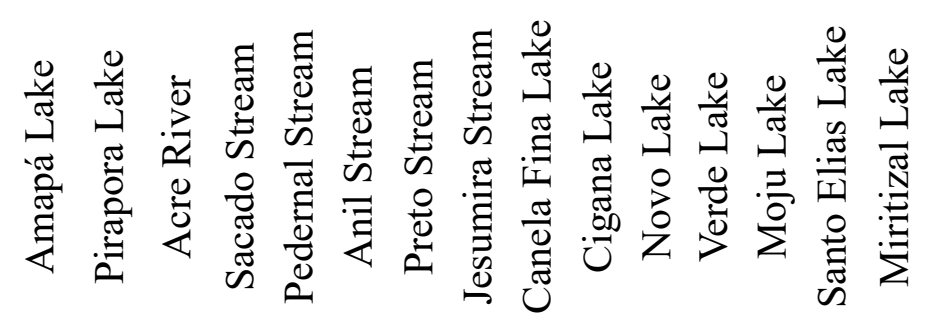

\section{Cladocera}

Alona cambouei (Guerne \& Richard, 1893)

$\mathrm{X}$

Alona glabra (Brehm, 1909)

$\mathrm{X}$

Alona sp. (Bourd, 1843)

$\mathrm{X}$

Alona sp. cf.

X

Alona sp.

$\mathrm{X}$

Alonella sp.

X

$\mathrm{X}$

Bosmina tubicen (Brehm, 1953)

$\mathrm{X}$

$\mathrm{X}$

Bosminopsis deitersi (Richard, 1895)

$\mathrm{X} \quad \mathrm{X} \quad \mathrm{X}$

$\mathrm{X} \quad \mathrm{X} \quad \mathrm{X}$

Ceriodaphnia cornuta (Sars, 1885)

X $\quad X \quad X$

Chydorus sp. (Stebling, 1902)

$\mathrm{X}$

Chydorus sp.

Daphnia gessneri (Herbst, 1967)

X X

$\mathrm{X}$

Daphnia sp.

$\mathrm{X} \quad \mathrm{X}$

Diaphanosoma brachyurum (Liévin, 1848)

$\mathrm{X}$

$\mathrm{X}$

Diaphanosoma brevireme(Sars, 1901)

$\mathrm{X}$

Diaphanosoma sp.

Diaphanosoma sp. (Fischer, 1859)

X $\quad X$

Diaphanosoma spinulosum Herbst, $1975 \quad$ X X

Disparalona dadayi (Birge, 1910)

$\mathrm{X}$ 
Disparalona sp.

Ephemeroporus sp.

Eurycercus lamellatus (O. F. Müller, 1776)

Ilyocryptus spinifer (Herrick, 1882)

Kurzia polyspina (Hudec, 2000)

Latonopsis sp.

Macrothrix sp.

Moina minuta (Hansen, 1899)

Moina reticulata (Daday, 1905)

Moina sp.

Pleuroxus sp.

Simocephalus latirostris cf. (Stingelin,

1906)

Simocephalus vetulus (O. F. Müller, 1776)

\section{Copepoda}

\section{Calanoida}

Calodiaptomus perelegans(Wright S, 1927) X X

Calodiaptomus spp.

X X

Notodiaptomus coniferoides(Wright S,

\section{Cyclopoida}

Mesocyclops meridianus(Kiefer, 1926)

Mesocyclops sp.

Microcyclops sp.

Neutrocyclops brevifurca (Lowndes, 1934)

Thermocyclops $\mathrm{sp}$.

Copepodites

Nauplii

\section{X}

X
X

X

X

$\mathrm{X}$

X $\quad$ X

X

$\mathrm{X} \quad \mathrm{X} \quad \mathrm{X} \quad \mathrm{X} \quad \mathrm{X}$

X

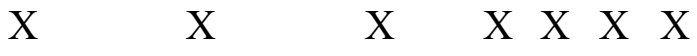
X

X 
14

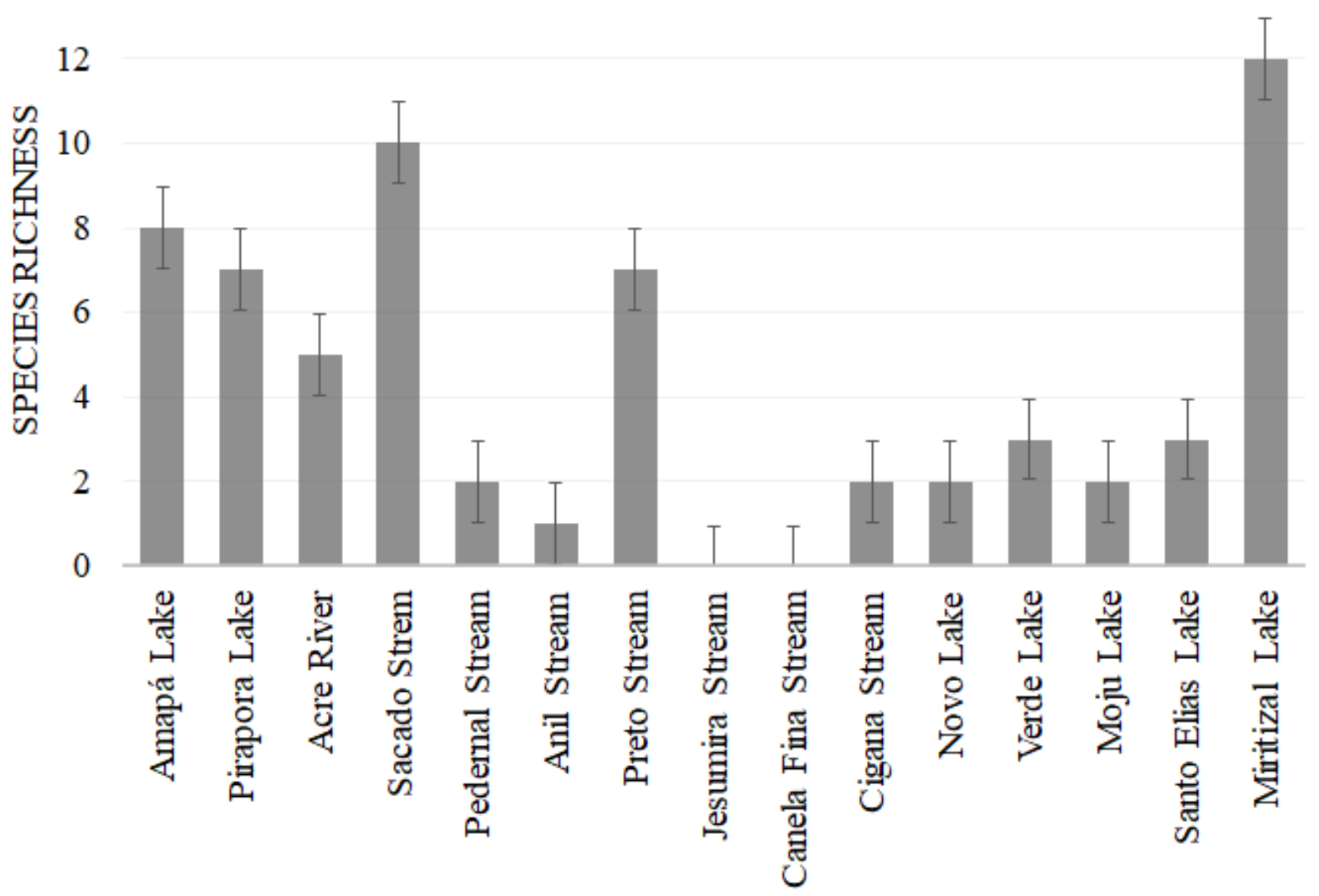

Figure 3. Cladocera and Copepoda species richness in each environment in previously published papers of Acre State. Brazil.

that some families were important contributors to rotifer populations in floodplain environments, including Lecanidae and Brachionidae among them, also observed in previous studies. Only half of the species were common to the surveys undertaken in the Acre River and its tributaries (Sendacz \& Melo-Costa 1991), Amapá Lake (known to be a polluted environment), and Pirapora Lake (Keppeler 2003a, b, Keppeler \& Hardy 2004a), excluding the species Colurella sp., Lecane lunaris, Lecane quadridentata, Lecane kutikova, Monomotta sp., Dissotrocha aculeata, Dissotrocha sp1, Dissotrocha sp2, and Macrochaetus sp., which were recent occurrences in Acre.

Keppeler et al. (2010) recorded the occurrence of two new species of rotifers in Acre: Keratella lenzi and Lecane monostyla. The first occurrence of Keratella lenzi in Acre was recorded at Jesumira stream, in the Serra do Divisor National Park. The genus Lecane of the family Lecanidae (Segers, 2004) is common in shallow and littoral waters, as well as in eutrophic environments such as ports, meandering lakes, and river mouths. In terms of geographic distribution, these organisms are considered hot stenothermal species with pantropical distributions (Ridder 1981).

In studies of zooplankton composition in Alto Juruá lakes, the rotifer class was found predominantly, distributed in 15 families (Santos et al. 2013), this same pattern was observed for Acre and other states in recent studies, by Nascimento and Keppeler (2017) in the Juruá River sub-basin; by Hardy and Keppeler (2004) at Amapá lake and by Santos et al., 2014 at Reserva Cuniã. The most common genera of Rotifera were Lecane and Brachionus, the most frequent families were Lecanidae, Lepadellidae, Keratellidae, Testudinellidae and Trichocercidae (Table 2). Some species had restricted occurrence to only one of the lakes that followed the study, as is the case of Kerantella lenzi helíaca (Berzins, 1995), Lecane acus (Harring, 1993). The study found five new occurrences for the state of Acre: Asplanchna cf. herricki (Novo Lake), Anuraeopsis coelata (Novo and Verde lakes), Testudinella cf. aspis (Verde Lake), Floscularia sp. (Novo, Verde and Cigana lakes) and Lepadella acrobeles (Moju lakes). The studied lakes, in general, presented different compositions, only Moju and Cigana lakes showing high similarity. Novo lake presented a different pattern in relation to the species found, as there is a division that separates Moju and Cigana lakes from Santo Elias and Verde lakes. This separation was also evident in the analysis of main components considering the first two components, managing to retain $77.5 \%$ of the original variation. This difference in lakes is possibly associated with the migration of species from the river to the lakes or vice versa.

The most frequent species in Novo Lake were Brachionus falcatus, followed by Notommata sp., while the most frequent species in Verde Lake was Brachionus caudatus. In Cigana Lake, the most frequent species were Notommata sp., Trichocerca similis, and Polyarthra vulgaris. In Moju Lake, the most frequent species were Brachionus 
caudatus, Brachionus dolabratus, and Brachionus falcatus. In Santo Elias Lake, Brachionus caudatus, Brachionus dolabratus, Notommata sp., Polyarthra vulgaris, and Brachionus. falcatus were most common. The species with the greatest abundance were the rotifers Keratella cochlearis, Polyarthra vulgaris, and Trichocerca similis, which were also numerous in Pirapora and Amapá lake (Keppeler 2003, Keppeler \& Hardy 2004). The species were typically not restricted to any single lake, occurring commonly in meandering lakes, such as Pirapora and Amapá lakes (Keppeler 2003, Keppeler \& Hardy 2004). The richness and abundance of the zooplankton species in the lakes studied were similar to observations made in other tropical and subtropical systems, with Rotifera showing a wide geographical distribution.

Silva et al. (2014) studied the zooplanktonic composition in Pedernal and Anil streams. For both water bodies, the most common rotifer families were Lecanidae (18 species) and Lepadellidae ( 7 species). There were 21 species newly recorded for the state of Acre. The species were generally found at low frequency, with their seasonal distributions not revealing any clear trends for the rainy and dry periods. Even the most frequent species showed similar values for the different seasons, in contrast to the results of other investigations in Lakes Amapá and Pirapora (Keppeler 2003a, b, Keppeler \& Hardy 2004a, b). This difference could be explained by the lower frequencies observed for the populations.

Nascimento and Keppeler (2017) studied the zooplankton population with a focus on rotifers in the southeastern basin. The most prevalent family was Lecanidae, characterized as typically being non-planktonic (Joko et al. 2008). Also significant was the family Lepadellidae, which is common in environments where Lecanidae occurs, as reported by Pradham et al. (2011) and Lima et al. (2012). The eight occurrences for the state of Acre were Pleuroxus sp. and Ephemeroporus sp., at the genus level, while at the species level, the organisms present were Adineta gracilis, Mytilina bisulcata, Gastropus stylifer, Lecane sola, Macrochaetus sericus, and Macrochaetus collinsi.

Richness and diversity of rotifers were observed in the Juruá River floodplain by Santos Nascimento \& Keppeler (2017). In total, 85 species were found throughout the study, 73 of Rotifera and 12 of Cladocera. Lecanidae, Brachionidae, and Lepadellidae were the most represented families, with 17, 14, and 10 species, respectively. In this study, eight new species were also reported for the state of Acre. Silva et al. (2014) registered 45 species of Rotifera, 21 being new occurrences for the state. Lecanidae and Lepadellidae are common in the tropics according to Lucinda et al. (2004).

Cladocerans and copepods were reported in the Jurua and Purus basins. The cyclopoid copepods were mainly represented by Thermocyclops sp., present in both the river and the lakes, notably in Lakes Lua Nova and Amapá. Mesocyclops meriadinus brevifurca was only recorded in the second phase of collection (in February 1988), principally in Lake Amapá. It should be noted that copepodites and nauplii were found in all the water bodies studied.

Keppeler (2003a) observed that at the bottom of lakes, cladocerans and copepods were more frequent than rotifers. The use of Pearson's correlation coefficient revealed that the cladocerans Moina spp. (Moina minuta and Moina reticulata) were correlated with physical and chemical parameters (water temperature $\left[{ }^{\circ} \mathrm{C}\right]$, transparency and depth of the water column $[\mathrm{m}]$, electrical conductivity $\left[\mu \mathrm{S} \mathrm{cm}^{-1}\right]$, turbidity [NTU], and dissolved oxygen $\left[\mathrm{mg} \mathrm{L}^{-1}\right]$ ), while Ceriodaphnia cornuta and Daphnia gessneri were correlated with Chaoboridae. The cladoceran populations were larger during the nighttime period, acting as a strategy against predation and explaining the positive correlation between Chaoboridae and Daphnia gessneri. Food may be the main factor acting to suppress zooplankton (Arcifa et al. 1992). The flood period results in greater dilution of food, making it less accessible to the zooplankton community. In addition, adequate oxygen concentrations are crucial for aquatic invertebrates (Hardy 1992), as described in several studies of lakes and reservoirs in the Amazon (Junk 1973, Brandorff 1977, Fisher et al. 1983).

Copepods constituted the most representative species in all studies. According to Robertson \& Hardy (1984), zooplankton communities in the Amazon are characterized by rotifers presenting the greatest diversity of species, while copepods occurred more, due to the presence of the juvenile stages (nauplii and copepodites). Keppeler (2003b) recorded the cladoceran species Bosminopsis deitersi, Ceriodaphnia cornuta, Diaphanosoma spinulosum, and Moina minuta. Keppeler (2003b) saw that Lakes Amapá and Pirapora both showed a high prevalence of Moina minuta throughout the study, while there was low representation of microcrustaceans (principally calanoids). Cyclopoida was represented by four genera: Thermocyclops, Mesocyclops, Microcyclops, and Neutrocyclops.

In the reservoir of the Canela Fina dam, Oliveira et al. (2010) found 7 species of cladocerans and 1 copepod, with predominance of Cladocera. The genus Alona sp. and the species Simocephalus latirostris were new discoveries in Acre. The families identified were Chydoridae, Daphnidae, Bosminidae, Macrothricidae, Moinidae, Ilyocryptidae, and Sididae, which are commonly found in most continental water environments (Sendacz 1993), including in the Amazon (Robertson \& Hardy 1984, Keppeler \& Hardy 2004b) and elsewhere in South America (Korovchinsky 2006). In the case of copepods, both environments showed the frequent presence of nauplii and copepodites. The existence of environmental stress in aquatic systems may hinder the development of these organisms up to the adult stage (Keppeler \& Hardy 2004b).

Santos et al. (2013) showed three species of cladocerans and various copepods were found. The cladocerans were represented only by Bosminidae and Moinidae and occurred in all the lakes, with the exceptions of Moina spp. in Lake Novo and B. deitersi in Lake Cigana and Lake Moju. Moina cf. minuta was the only species present in all the lakes. In the case of copepods, only the larval forms (nauplii and copepodites) were frequent in the five environments studied.

In the study by Nascimento \& Keppeler (2017), the Cladocera genus Alona sp. was highlighted, contributing $44.4 \%$ and $29 \%$ in two different months. Two new genera for Acre were observed: Pleuroxus and Ephemeroporus, which are both common in Brazil (Elmoor Loureiro 2014). There was a greater presence of cladocerans than observed in other ecosystems of Acre, such as Lake Amapá in Rio Branco (Keppeler $\&$ Hardy 2004a), which could have been due to the presence of aquatic macrophytes. The family Chydoridae, also found in this study, was observed elsewhere (in the Alto Paraná), where it was associated with aquatic macrophytes (Serafim-Júnior et al. 2006).

Santos Nascimento \& Keppeler (2017) found 12 species of Cladocera, with the species Alonella brasiliensis as a new occurrence in the state of Acre. There was a greater species quantity found compared to the previously mentioned studies. The authors reported that their greatest abundance was during the flood. In 2004, Yamamoto found that the abundance of zooplankton increased during the flood because of the availability of more resources. 
Despite the large number of variables analyzed among the studies, few have considered the seasonal changes in the zooplankton populations during the entire annual cycle, generally being registered only in some dry (June to September) and rainy (December to March) months. In general, reports in the literature have addressed spatial variability, specific diversity indices, equitability, diurnal variation, the coastal zone, and vertical distribution. Among these aspects, the diurnal variation, the fauna associated with macrophytes, and collections in the coastal and limnetic zones were mentioned in only $15 \%$ of the consulted reports. Thus, it is important to emphasize that in addition to the most studied aspects, seasonality is also a relevant factor for examining zooplankton species, as shown by the studies by Araujo et al. (2019) and Cabral et al. (2020), in which the authors took into consideration this aspect and obtained greater species richness in the studied environments for the state of Acre.

It is also important to consider the sampling effort and its effects when analyzing the species richness and composition and this analysis was not possible due to the lack of information on total number of samples or volume filtered in the previous studies. Bottrel et al. (1976) and Ghidini \& Santos-Silva (2018) discussed that different sampling gear, effort, and other environmental conditions can affect results regarding species composition, especially when considering rarer species.

Knowledge of zooplankton in the state of Acre is limited by several factors, notably the inherent taxonomic difficulties and problems with accessing the wide range of ecosystems, many of which may be temporary. The scarcity of studies covering entire hydrological (annual) cycles, together with the spatial limitations (both horizontal and vertical) of studies, are major challenges for researchers endeavoring to understand the real biodiversity of this group of organisms in Acre. Therefore, these gaps in knowledge remain to be addressed in future studies.

The present study provides an important synthesis of the current understanding of zooplankton biodiversity in the state of Acre, serving as a basis for future monitoring studies of basins and/or the implementation of programs for the conservation of species biodiversity and ecosystems. It is suggested that intensified research concerning this group of organisms should be carried out for other environments within Acre, including lotic ecosystems. Other issues to be considered in future studies of zooplankton biodiversity in this region are the characterization of limnetic zones of ecosystems and the compilation of inventories for species typical of temporary limnic environments. The results obtained in this bibliographic survey contribute to understanding the biodiversity and species distributions of zooplankton in different biomes in Brazil.

\section{Acknowledgments}

The authors would like to thank the support of LabLimno Limnology Laboratory of Acre's Federal University (Centro de Ciências Biológicas e da Natureza / Universidade Federal do Acre) for infrastructure as well as Dr. Edinaldo Nelson dos Santos-Silva (Instituto Nacional de Pesquisas da Amazônia - INPA) and Dr. Maria Rosélia Marques Lopes (Universidade Federal do Acre - UFAC) for contributing with bibliographic references and MSc. Ronaldo Souza da Silva for the construction of the map in this paper.

\section{Author Contrubutions}

Larissa Araújo dos Santos: Contribution in the concept of the study; data collection; data analysis and interpretation; manuscript preparation; contribution to critical revision, adding intellectual content.

Andressa Crystine Souza da Silva: Contribution in the concept of the study; data collection; data analysis and interpretation; manuscript preparation; contribution to critical revision, adding intellectual content.

Pedro Paulo Pereira: Contribution in the concept of the study; data collection; data analysis and interpretation; manuscript preparation; contribution to critical revision, adding intellectual content.

Ronnilda Maria Gonçalves Araujo: Contribution in data analysis and interpretation; manuscript preparation; contribution to critical revision, adding intellectual content.

André Ricardo Ghidini: Contribution in the concept of the study; data collection; data analysis and interpretation; manuscript preparation; contribution to critical revision, adding intellectual content.

\section{Conflicts of interest}

The authors declare that they have no conflict of interest related to the publication of this manuscript.

\section{References}

ACRE. 2012. Secretaria de Estado de Meio Ambiente. Plano estadual de recursos hídricos do Acre. 1 ed. Rio Branco, SEMA.

ALLAN, J. D. 1976. Life history patterns in zooplankton. Am. Nat. 110(971): 165-180.

ANA. 2011. Plano estratégico de recursos hídricos da bacia Amazônica: afluentes da margem direita. Agência Nacional de Águas: Brasília. MARGEM DIREITA. http://margemdireita.ana.gov.br/ (Last access in: 25/10/2019)

AOYAGUI, A. S .M. \& BONECKER, C. C. 2004. The art status of rotifer studies in natural environments of South América: Floodplains. Acta scientiarum. 26(4): 385-406.

ARAÚJO, L. E. et al. 2009. Bacias hidrográficas e impactos ambientais. Qualitas Revista Eletrônica. 8(1).

ARAUJO, R. M. G. 2019. Variação espacial da comunidade de zooplâncton no igarapé São Francisco, Rio Branco, Acre.

ARCIFA, M. S., GOMES, E. A. T., \& MESCHIATTI, A. J. 1992. Composition and fluctuations of the zooplankton of a tropical Brazilian reservoir. Arch. Hydrobiol. 129: 479-495.

BIRKY JR, C. W., \& GILBERT, J. J. 1971. Parthenogenesis in rotifers: the control of sexual and asexual reproduction. Am. zool. 11(2): 245-266.

BOTTREL, H.H., DUNCAN, A., GLIWICZ, Z.M., GRYGIEREK, E., HERZIG, A., HILlBRICHT-ILKOWSKA, A., KURASAWA, H., LARSSON, P. AND WEGLENSKA, T. 1976. A review of some problems in zooplankton production studies. Norw. J. of Zoo. 24: 419-456.

BOZELLI, R. L. 1992. Composition of the zooplankton community of Batata and Mussurá Lakes and of the Trombetas River, State of Pará, Brazil. Amazoniana: Limnologia et Oecologia Regionalis Systematis Fluminis Amazonas. 12(2): 239-261.

BRANDORFF, G. O. 1977. Untersuchungen zur Populationsdynamik des Crustaceenplanktons im tropischen Lago Castanho (Amazonas, Brasilien). Christian-Albrechts-Universitaet.

BRANDORFF, G. O., KOSTE, W., \& SMIRNOV, N. N. 1982. The composition and structure of rotiferan and crustacean communities of the lower Rio Nhamundá, Amazonas, Brazil. Stud. Neotrop. Fauna Environ. 17(2-3): 69-121.

CABRAL, G. S. 2020. Efeito dos atributos da comunidade de macrófitas e das variáveis limnológicas sobre a comunidade de Cladóceros fitófilos. 
CARDOSO, L. S., RAMOS, J. D., \& DE OLIVEIRA MELLO, H. O. 2008 Composição, densidade e abundância das populações de cladocera, copepoda e rotífera de áreas de proteção permanente do Rio Uberabinha. Em Extensão. 7(2): 95-106

CARVALHO, M. L. 1983. Efeitos da flutuação do nível da água sobre a densidade e composição do zooplâncton em um lago de várzea da Amazônia, Brasil. Acta Amazon. 13(5-6): 715-724.

COLLIER, C. A., NETO, M. S. A., ALMEIDA, G. M. A., ROSA FILHO, J. S., SEVERI, W. \& EL-DEIR, A. C. A. 2019. Effects of anthropic actions and forest areas on a neotropical aquatic ecosystem. Sci. Total Environ. 691: 367-377.

DUMONT, H. J. 1983. Biogeography of rotifers. In: Biology of Rotifers. Developments in Hydrobiology. Springer, Dordrecht.14:19-30.

ELMOOR-LOUREIRO, L. M. 2014. Ephemeroporus quasimodo sp. nov. (Crustacea: Cladocera: Chydoridae), a new species from the Brazilian Cerrado. Zootaxa. 3821(1): 88-100.

ESTEVES, F. A. 1998. Fundamentos de limnologia. Interciência.

FISHER, T.R., MELACK, J. M., ROBERTSON, B., HARDY, E. R. \& ALVES, L. F. 1983. Vertical distribution of zooplankton and physico-chemical conditions during a 24-hour period in an Amazon floodplain lake-Lago Calado, Brazil. Acta Amazon. 13(3-4): 475-487.

GALVÃO, M. C. B. 2010. O levantamento bibliográfico e a pesquisa científica. Fundamentos de epidemiologia. 2 ed. A, v. 398. p. 1-377.

GARCÍA, A. M. et al. 2016. Regional effects of agricultural conservation practices on nutrient transport in the Upper Mississippi River Basin.Environ. Sci. Technol. 50(13): 6991-7000.

GHIDINI, A. R., CALIXTO, L. S. E. F. \& DA SILVA BANDEIRA, M. G. 2018. Contribuição para o conhecimento da composição e diversidade do zooplâncton de quatro lagos de Várzea na região de Itacoatiara, Amazonas, Brasil. South American Journal of Basic Education, Technical and Technological. 5(2).

GHIDINI, A. R. \& SANTOS-SILVA, E. N. 2009. Biomassa de quatro espécies de Cladocera (Crustacea: Branchiopoda) e sua variação nictemeral no Lago Tupé, Amazonas, Brasil. In: SANTOS-SILVA, E. N.; SCUDELLER, V. V. (orgs) Biotupé: Meio Físico, Diversidade Biológica e Sociocultural do Baixo Rio Negro, Amazônia Central. Editora UEA Ltda: Manaus. v. 2. p. 53-62

GHIDINI, A.R. \& SANTOS-SILVA, E. N. 2018. Composition, abundance, and diversity of limnetic cladocerans (Crustacea: Anomopoda and Ctenopoda) in a blackwater lake in the Negro River basin, Amazonas State, Brazil. Nauplius (26): e2018018.

GROOMBRIDGE, B. 1992. Global biodiversity: status of the earth's living resources. Chapman \& Hall, Londres.

HARDY, E. R. 1992. Changes in species composition of Cladocera and food availability in a floodplain lake, Lago Jacaretinga, Central Amazon. Amazoniana: Limnologia et Oecologia Regionalis Systematis Fluminis Amazonas. 12(2): 155-168.

HARDY, E. R. 1980. Composição do zooplâncton em cinco lagos da Amazônia Central. Acta Amazon. 10(3): 577-609.

HARDY, E. R, ROBERTSON, B., \& KOSTE, W. 1984. About the relationship between the zooplankton and fluctuating water levels of Lago Camaleão, a Central Amazonian várzea lake. Amazoniana: Limnologia et Oecologia Regionalis Systematis Fluminis Amazonas. 9(1): 43-52.

HEYWOOD, V. H. 1995. The global biodiversity assessment. Cambridge University Press, Cambridge.

IBGE. Instituto Brasileiro de Geografia e Estatística. 2011. Atlas de saneamento. Ministério do Planejamento, Orçamento e Gestão. Rio de Janeiro: Diretoria de geociências.

IŞKIN, Uğur et al. Impact of Nutrients, Temperatures, and a Heat Wave on Zooplankton Community Structure: An Experimental Approach. Water. 12(12): 3416, 2020.

JOKO, C. Y., LANSAC-TÔHA, F. A. MURAKAMI, E. A., \& BONECKER, C. C. 2008. Novas ocorrências de Lecane no plâncton de distintos ambientes da planície de inundação do alto rio Paraná Brasil. Acta Sci. Biol. Sci. 30(2): 165-171.
JUNK, W. J. 1973. Investigations on the ecology and production-biology of the" floating meadows"(Paspalo-Echinochloetum) on the Middle Amazon. Part II. The aquatic fauna in the root zone of floating vegetation. Amazoniana: Limnologia et Oecologia Regionalis Systematis Fluminis Amazonas. 4(1): 9-102.

KARPOWICZ, M, EJSMONT-KARABIN, J., KOZLOWSKA, J., FENIOVA, I., \& DZIALOWSKI, A. R. 2020. Zooplankton community responses to oxygen stress. Water. 12(3): 706.

KEPPELER, E. C. 2003a. Abundance of zooplankton for different zones (pelagic and littoral) and time periods (morning and night) in two Amazonian meandering lakes. Acta Sci. Biol. Sci. p. 287-297.

KEPPELER, E. C. 2003b. Comparative study of the zooplankton composition of two lacustrine ecosystems in Southwestern Amazonia. Acta Sci. Biol. Sci. p. 467-477.

KEPPELER, E. C. \& HARDY, E. R. 2004a. Vertical distribution of zooplankton in the water column of Lago Amapá, Rio Branco, Acre, Brasil. Rev. Bras. Zool. p. 169-177.

KEPPELER, E. C. \& HARDY, E. R. 2004b. Abundance and composition of Rotifera in abandoned meander lake (Lago Amapá) in Amazonia. Rev. Bras. Zool. p. 233-241.

KEPPELER, E. C., SOUZA, S. L. S., SILVA, E. S., SERRANO, R. O. P., SOUZA, R. M., DANTAS, I. I. S., SILVÉRIO, J. F., \& MADEIRA, F. P. 2010a. Rotifera, Eurotatoria, Lecanidae, Lecane monostyla (daday, 1897): new occurrence for state of Acre. Ciên. Biol. Agr. S. p. 9-14.

KEPPELER, E. C., SILVA, E. S., SOUZA, R. M., OLIVEIRA, E. A., SOUZA, A. S. \& MADEIRA, F. P. 2010b. Keratella lenzi (Hauer, 1953): a new occurrence for Acre State, Brazil, specifically in Igarapé Jesumira located in Parque Nacional da Serra do Divisor. Biotemas. p. 219-221.

KOROVCHINSKY, N. M. 2006. The Cladocera (Crustacea: Branchiopoda) as a relict group. Zool. j. Linn. Soc. 147(1): 109-124.

KOSTE, W. \& ROBERTSON, B. 1983. Taxonomic studies of the Rotifera (Phylum Aschelminthes) from a Central Amazonian varzea lake, Lago Camaleão (Ilha de Marchantaria, Rio Solimões, Amazonas, Brazil). Amazoniana: Limnologia et Oecologia Regionalis Systematis Fluminis Amazonas. 8(2): 225-254.

LAIR, N. 2006. A review of regulation mechanisms of metazoan plankton in riverine ecosystems: aquatic habitat versus biota. River Res. Appl.. 22(5): 567-593.

LANSAC-TÔHA, F. A., BONECKER, C. C., VELHO, L. F. M., SIMÕES, N. R., DIAS, J. D., ALVES, G. M., \& TAKAHASHI, E. M. 2009. Biodiversity of zooplankton communities in the Upper Paraná River floodplain: interannual variation from long-term studies. Brazilian Journal of Biology, 69(2): 539-549.

LIMA, P. V., OLIVEIRA, S. M. L., DE CARVALHO SILVA, M., \& OLIVEIRA, V. A. 2012. Variação na riqueza das espécies zooplanctônicas em lagoas marginais do rio Cuiabá (Pantanal-MT). Biodiversidade. 11(1).

LUCINDA, I.; MORENO, I. H.; MELÂO, M. G. G.; MATSUMURA-TUNDISI, T. 2004. Rotifers in freshwater habitats in the upper tietê river basin, São Paulo State, Brazil. Acta Limnol. Bras., Botucatu. 16: 203-224.

NASCIMENTO, S. O. \& KEPPELER, E. C. 2017. Zooplâncton com ênfase em rotifera no balneário canhoto (igarapé sacado de Brasília) localizado na sub-bacia hidrográfica do rio Juruá, Cruzeiro do Sul, Acre. Rev. Bras. Zoociênc. 18(1): 91-102.

OLIVEIRA, E. A., DE FREITAS, J. S., KEPPELER, E. C., GOMES, C. G., DO NASCIMENTO, A. M., SERRANO, R. O. P., \& DA SILVA, A. J. A. 2010. Zooplâncton de dois ecossistemas aquáticos rasos, em áreas de incidência do Anopheles darlingi, no noroeste do Estado do Acre. Ens. Cienc: Cienc Biol, Agrar. Saúde. 14(2): 71-81.

PEJLER, B. 1977. General problems on rotifer taxonomy and global distribution. Arch. Hydrobiol. Ergebn. Limnol. 8: 212-220.

PINHEIRO, S., LIMA, M., CARNEIRO, B., TAVARES, V. C., \& CÂMARA, V. 2019. Effects of a shipwreck on the zooplankton community in a port region of the Amazon. Environmental Science and Pollution Research. 26(6): 5738-5750. 
PRADHAN, V., PATEL, R. \& BANSODE, S. G. 2011. Biodiversity of population dynamics and seasonal variation in NathSagar Reservoir at Paithan (MS) India, with reference to Rotifers. International Journal of Science Innovations and Discoveries.1(3): 320-326.

RIDDER, M. 1981. Some considerations on the geographical distribution of rotifers. Hydrobiologia. 85(3): 209-225.

ROBERTSON, B. A. \& Hardy, E. R. 1984. Zooplankton of Amazonian lakes and rivers. In: The Amazon. Springer, Dordrecht. p. 337-352.

ROCHA, O., SENDACZ, S., \& MATSUMURA-TUNDISI, T. 1995. Composition, biomass and productivity of zooplankton in natural lakes and reservoirs of Brazil. Limnology in Brazil, p. 151-165.

RUTTNER-KOLISKO, A. 1972. Rotatoria. Die Binnengewässer. 26(1): 99-234.

SANTOS, M. J. A., KEPPELER, E. C., VIEIRA, L. J. S., SERRA, A. J. \& FERRAUDO, A. S. 2013. Zooplankton composition in five oxbow lakes from the Upper Juruá River, Acre State, Brazil. Rev. Peru. Biol. 20(2): 137-144.

SANTOS NASCIMENTO, T. \& KEPPELER, E. C. 2017. Diversidade e riqueza de rotíferos de um lago meandrico da planície de inundação do Rio Juruá, Acre. Braz. J. Aquat. Sci. Technol, 21(1): 28-36.

SANTOS, R. M., NEGREIROS, N. F., \& SILVA, L. C. 2014. Community composition and biomass zooplanctônica in canal Cuniã, river basin Wood, Amazon. X Fórum Ambiental da Alta Paulista. 10(3): 188-201.

SEGERS, H. 2007. Annotated checklist of the rotifers (Phylum Rotifera), with notes on nomenclature, taxonomy and distribution. Zootaxa. 1564(1): 1-104.

SEGERS, H. 2004. Rotifera: Monogononta. In: YULE, C.M.; YONG, H.S. (Eds.). Freshwater Invertebrates of the Malaysian Region. Kuala Lumpur: Academy of Sciences of Malaysia. p. 106-120.

SENDACZ, S. \& MELO-COSTA, S. S. 1991. Caracterização do zooplâncton do Rio Acre e lagos Lua Nova, Novo Andirá e Amapá (Amazônia, Brasil). Rev. Bras. Biol. p. 455-462.
SENDACZ, S. 1993. Distribuição geográfica de alguns organismos zooplanctônicos na América do Sul. Acta Limnol. Bras. v. 6. p. 31-41.

SENDACZ, S., CALEFFI, S. \& SANTOS-SOARES, J. 2006. Zooplankton biomass of reservoirs in different trophic conditions in the state of São Paulo, Brazil. Braz. J. Biol. v. 66. p. 337-350.

SERAFIM-JÚNIOR, M., NEVES, G. P., BRITO, L. \& GHIDINI, A. R. 2006. Zooplâncton do rio Itajaí-Acú a jusante da cidade de Blumenau, Santa Catarina, Brasil. Estud. Biol. 28(65).

SETUBAL, R. B., PETRY, A. C., BONECKER, C. C., MARTINS, T., NOVA, C. C., FIGUEIREDO-BARROS, M. P., \& BOZELLI, R. L. 2020. Biotic factors determine ecosystem processes in environments with different hydrological regimes. Freshw. Biol. 65(8): 1376-1391.

SHARMA, B. K. \& SHARMA, S. 2001. Biodiversity of Rotifera in some tropical floodplain lakes of the Brahmaputra river basin, Assam (NE India). In: Rotifera IX. Springer, Dordrecht. p. 305-313.

SILVA, E. S., KEPPELER, E. C., \& SILVÉRIO, J. F. 2014. Composition of zooplankton at the small rivers Pedernal and Anil, Serra do Divisor National Park, Acre, Brazil. SaBios-Revista de Saúde e Biologia. 9(1): 86-94.

SOUZA, C. A. D., VIEIRA, L. C. G., LEGENDRE, P., CARVALHO, P. D., VELHO, L. F. M., \& BEISNER, B. E. 2019. Damming interacts with the flood pulse to alter zooplankton communities in an Amazonian river. Freshw. Biol. 64(5): 1040-1053.

WANTZEN, K. M., JUNK, W. J. \& ROTHHAUPT, K. O. 2008. An extension of the floodpulse concept (FPC) for lakes. In: Ecological effects of water-level fluctuations in lakes. Springer, Dordrecht. p. 151-170.

YAMMAMOTO, K. C. 2004. Alimentação de Triportheus angulatus (Spix \& Agassiz, 1829) no lago Camaleão, Manaus, AM, Brasil. Acta Amazon. 34: 653-659.

Received: 16/09/2021

Accepted: 10/11/2021

Published online: 08/12/2021 